\title{
Dry matter accumulation, distribution and fresh tuber yield of grafted accessions of Hausa potato
}

\author{
K.K. NANBOL \& O.A.T. NAMO* \\ (K.K.N \& O.A.T.N.: Cytogenetics and Plant Breeding Unit, Department of \\ Plant Science and Biotechnology, University of Jos, P.M.B. 2084, Jos, Nigeria) \\ *Correspondingauthor's email: akunamo@yahoo.co.uk
}

\begin{abstract}
The Hausa potato is a minor tuber crop with nutritional and medicinal values. A lack of balance between the photosynthetic source potential and the sink capacity in terms of dry matter accumulation and distribution is believed to affect fresh tuber yield. This study was aimed to investigate the dry matter production, distribution and tuber yield of reciprocal grafts of some accessions of the Hausa potato. The grafts were made in all possible combinations and laid out using the completely randomized design in four replicates. Results showed that harvest index increased with time in most of the grafts. The proportion of dry matter partitioned to the tubers was generally lower than those of the leaves and stems in all the grafts. The highest rootstockscion ratio of 0.97 was observed in the graft Bokkos 2 - Manchok 2 while the lowest $(0.07)$ was observed in the self-graft of Bokkos 2. Fresh tuber yield was generally low, ranging from $0.03 \mathrm{t}$ $\mathrm{ha}^{-1}$ to $0.09 \mathrm{tha}^{-1}$ Apart from dry matter accumulation and distribution, the relationship between the source potential and sink capacity as well as the rate of translocation of assimilates from the photosynthetic source to the sink need to be investigated.
\end{abstract}

Keywords: Hausa potato; reciprocal grafts; dry matter; source potential; sink capacity Original scientific paper. Received 19 Nov 2019; revised 21 Oct 2020

\section{Introduction}

The Hausa potato (Solenostemon rotundifolius [Poir) J. K. Morton] is a small herbaceous annual crop with a distinctive fragrance and peculiar tuber taste (Alleman, 2002; PROTA, 2013). The leaves are used to treat dysentery, blood in urine and eye disorders. The tubers are eaten as a main starchy staple or part of it in combination with legumes, vegetables or cereals. The Hausa potato plays a very significant role in providing the dietary and energy requirements of the local people in Nigeria during lean periods. The crop is rich in major and minor nutrients and all the nutrients are reported to be essential for the proper functioning of the body (Kana et al., 2012).

According to Alleman (2002), the protein content in the Hausa potato, which is $14 \%$ on dry matter basis, compares well with Irish potato and sweetpotato as well as other tuber crops. The principal amino acids present in the protein are arginine, aspartic and glutamic acids (National Research Council, 2006). The tubers are also a rich source of dietary energy as $100 \mathrm{~g}$ of the tubers provide $392-394 \mathrm{KJ}$ of metabolisable energy (Schoeninger et al., 2000; PROTA, 2013) and 28.62\% starch content on dry matter basis (Ukpabi et al., 2011). The

Ghana Jnl Agric. Sci. 55 (2), $86-96$

GJAS is an Open Access Journal and distributed under the terms of the Creative Commons (CC) License [CC BY 4.0] 
crop is popular in the middle belt and the northeastern part of Nigeria. The importance of the Hausa potato as a staple foodstuff in the tropics has been largely replaced by other starchy foodstuffs such as sweetpotato; consequently, production has declined to such an extent that it has almost disappeared in many areas (Oteng-Yeboah \& Bennett-Lartey, 2008). The Hausa potato is an important crop that has contributed immensely in alleviating poverty, hunger and starvation in various farm-families. Properly directed researches to find solutions to the many agronomic and storage-health challenges besetting the crop is imperative towards making the crop to achieve its full quantitative and qualitative yield potentials and contributing to the drive for food security in Nigeria.

Yield is the product of photosynthetically active radiation (PAR) and its conversion efficiency to dry matter (radiation use efficiency). For root and tuber crops like the Hausa potato, the ability of the leaves (source) to convert the PAR into carbohydrates and the storage capacity of the tubers (sink) affect the potential growth of the individual tubers and crop yield (Oliveira et al., 2016). In other words, the fresh tuber yield is affected by the size and activity of the source and sink as evidenced in the dry matter production and distribution. Grafting methods have been used to study the interrelationship between the source and the sink (Namo, 2005).

The production of dry matter by the photosynthetic source and its translocation to the tuberous root determines, to a large extent, the size of the tubers and consequently the fresh tuber yield (Tekalign \& Hammes, 2005a). Dry matter production influences the growth and yield of root and tuber crops due to its relationship with the growth and photo- assimilate storage (Tekalign \& Hammes, 2005b). There are differences in dry matter accumulation in the leaves, stems and tubers, which correspond to the moment with greater accumulation and duration of biomass in a particular organ (Ñústez et al., 2009). This study was aimed to investigate the pattern of dry matter accumulation, distribution and fresh tuber yield of grafted accessions of the Hausa potato in the Jos-Plateau, Nigeria.

\section{Materials and Methods}

The experiment was conducted between April and October, 2018 at the Federal College of Forestry Jos, Plateau State (Latitude $09^{\circ} 30^{\prime} \mathrm{E}$ and Longitude $08^{\circ} 20^{\prime} \mathrm{N}$, Altitude $1,159 \mathrm{~m}$ above sea level). Four accessions of the Hausa potato used in this study were sourced from the locations shown in Table 1.

\section{Soil analysis}

Composite soil samples were taken in the $0-5 \mathrm{~cm}$ depth before planting using soil auger. The soil samples were analysed for texture, $\mathrm{pH}$, total nitrogen, organic carbon, phosphorus, potassium and particle size (sand, silt and clay), clay percentage, silt percentage, sand percentage and textural class. The physico-chemical properties of the soil samples are shown in Table 2.

\section{Grafting of the Hausa Potato}

80 sprouted tubers of each of the accessions were planted in black polyethylene bags filled with topsoil, manure and river sand in a potting ratio of $3: 2: 1$, respectively (Namo, 2005). Eight weeks after planting, when all the sprouted tubers have emerged, reciprocal grafts of the four accessions were made in all possible combinations including four selfgrafts. For each graft-combination in each of 
the four accessions, four grafts were made, giving a total of 64 grafts. The cleft grafting technique was used. A scion with four or five fully developed leaves was pruned and grafted onto the rootstock. The grafted portion was wrapped with a grafting tape to prevent it from drying. It was thereafter covered with a white polyethylene bag to provide heat for the grafted portion and to ensure the successful union of the grafts. Two weeks after the graft union has been established, successful grafts were counted and recorded. All the pots were arranged using the completely randomised design in four replicates. The third and fourth replications were used for the growth analysis study. The grafts were pruned regularly to remove any sprout from the stock or tuber from the scion, so that only the scion was allowed to produce leaves which served as the main photosynthetic organs while the stock served as the non-photosynthetic organ (i.e. for tuber formation) (Namo, 2005). The pots were manually weeded in order to control weeds. 50 $\mathrm{g}$ of cow dung manure was applied to every plot at four weeks after grafting.

\section{Procedure and Technique used in the Grafting of Hausa Potato}

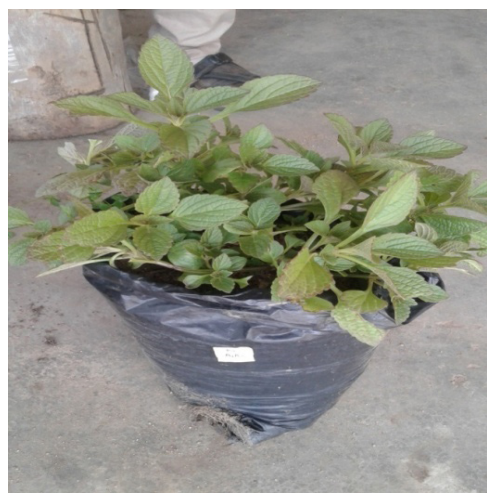

Fig. 1: Hausa potato plant grown at eight weeks after planting

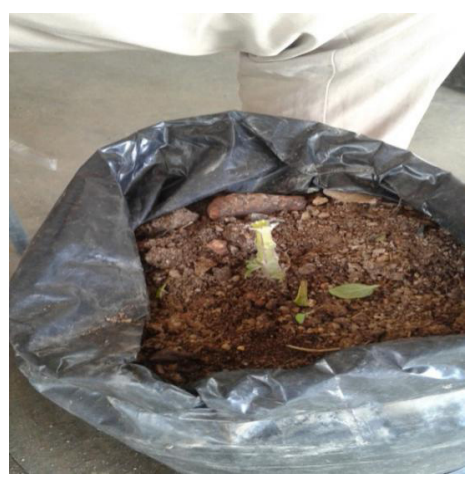

Fig. 2: Prepared rootstock of Hausa potato

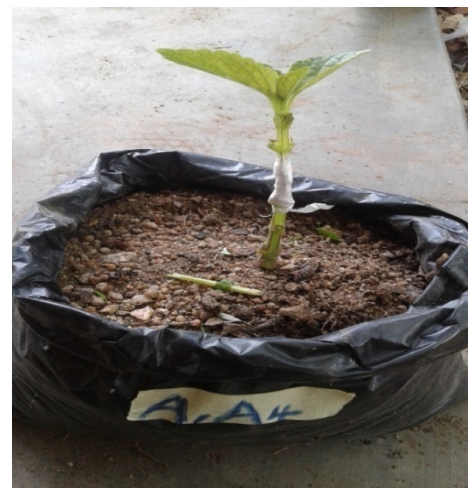

Fig. 3: A scion grafted on the rootstock

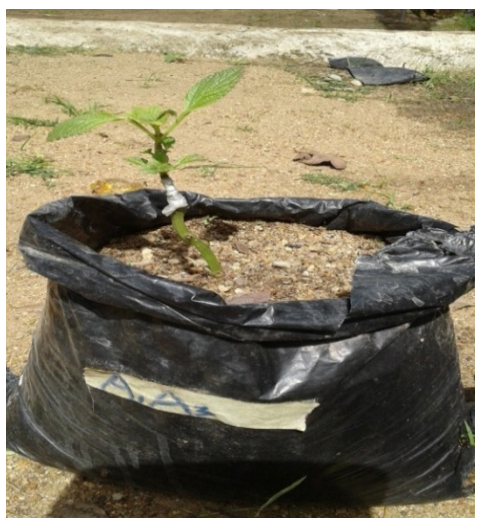

Fig. 4: A graft union of Hausa potato at four weeks after grafting 


\section{Dry matter accumulation and partitioning}

The total dry matter accumulated over time and the percentage distributed to various parts (leaves, stems and roots) were computed at 45 and 90 days after grafting. Each harvested plant was washed and separated into roots, stems and leaves. All the plant parts were placed in separate envelopes, labeled and dried in a moisture- extraction oven at $80^{\circ} \mathrm{C}$ for 48 hours to obtain constant dry weight. The total dry matter accumulated and the proportion distributed to the leaves, stems and roots were computed. Harvest index was computed as the ratio of the economically important portion of the yield (tuber) to the total biological yield of dry matter (Donald, 1962; Harper \& Ogden, 1970; Namo, 2005). Root-stock-scion ratio was computed as the ratio of the weight of tuber to the weight of shoot (Namo, 2005).

\section{Harvest Index $=\underline{\text { Dry weight of tubers }}$ Total dry weight \\ Rootstock-scion ratio $=\underline{\text { Weight of rootstock }}$ Weight of shoot}

All the tubers harvested from each plot at 120 DAG were weighed and the weight was converted to the equivalent in tonnes per hectare before the statistical analysis.

\section{Data Analysis}

Data collected were subjected to one-way analysis of variance (ANOVA) test, using the Statistical Analysis Software (SAS, 9.0 Version). Means were separated using Duncan's New Multiple- Range Test at 5\% level of probability.

\section{Results}

Dry matter accumulation in the leaves, stems and tubers varied from one graft-combination to the other (Table 3). The dry matter accumulation increased with time in the leaves and stems in all the graft combinations except in the graftcombination involving the accessions Langtang as stock and Manchok 2 as scion (Langtang - Manchok 2). The dry matter accumulation in the tubers increased with time in all graftcombinations but Langtang - Manchok 2 and the self-graft of NRCRI (White). The total dry matter accumulated increased with time in all the graft combinations except in the self-graft of the accession NRCRI (White). Irrespective of the stage of growth, more dry matter was accumulated in the leaves and the stems than in the tubers.

At 45 days after grafting, more dry matter was partitioned to the leaves and the stems than to the tubers in all the graftcombinations except in the self-graft of Manchok 2 (Table 4). At 90 days after grafting, the proportion of dry matter distributed to the leaves decreased in all graft-combinations except Langtang - NRCRI (White), Manchok 2 - Manchok 2, Manchok 2 - NRCRI (White), Manchok 2 - Langtang, NRCRI (White) Langtang and NRCRI (White) - Manchok 2.

On the other hand, the proportion of dry matter partitioned to the stems at $90 \mathrm{DAG}$ increased in all but the graft-combinations Langtang - NRCRI (White), Langtang Manchok 2, Manchok 2 - Manchok 2, Manchok 2 - NRCRI (White), Manchok 2 - Langtang, NRCRI (White) - Langtang and NRCRI (White) - Manchok 2. 
The proportion of dry matter partitioned to the tubers increased with time in all but the grafts Bokkos 2 - NRCRI (White), Manchok 2 - Manchok 2, Manchok 2 - NRCRI (White), Manchok 2 - Langtang, NRCRI (White) - NRCRI (White) and NRCRI (White) - Manchok 2. The percentage of dry matter distribution to the tubers was generally lower than that of the leaves and stems in all the graftcombinations at the end of the growing season. At 45 days after grafting (45 DAG), harvest index varied from 0.01 in the graft NRCRI (White) - Manchok 2 to 0.34 in the graft Bokkos 2 - Manchok 2 (Table 5). At 90 DAG, harvest index was lowest in the graft Bokkos 2 - Manchok 2 (0.04) and highest in the graft NRCRI (White) - Langtang (0.23) (Table 5.) Harvest index increased with time in all graft-combinations except Bokkos 2 - NRCRI (White), Bokkos 2 - Manchok 2, Langtang Langtang, Langtang - Manchok 2, Manchok 2 - Bokkos 2 and NRCRI (White) - NRCRI (White).

The highest rootstock- scion ratio of 0.97 was observed in the graft NRCRI (White) Bokkos 2 while the lowest (0.07) was observed in the self-graft of Bokkos 2. The mean stock effect on the rootstock-scion ratio varied from 0.39 in the accessions Bokkos 2 and Langtang to 0.57 in the accession NRCRI (White). The highest mean scion effect (0.67) was observed in the accession Manchok 2 while the lowest (0.19) was observed in the accession NRCRI (White) (Table 6).

The fresh tuber yield varied from 0.01 t ha ${ }^{-1}$ in the graft Bokkos 2 - NRCRI (White) to $0.09 \mathrm{t} \mathrm{ha}^{-1}$ in the graft Langtang-Bokkos 2 (Table 7). The graft-combinations differed in fresh tuber yield. The mean stock effect varied from $0.04 \mathrm{t} \mathrm{ha}^{-1}$ in the accession Bokkos 2 and Manchok 2 to $0.05 \mathrm{t} \mathrm{ha}^{-1}$ in the accessions
Langtang and NRCRI (White). The mean scion effect was highest in the accession Bokkos 2 $\left(0.07 \mathrm{tha}^{-1}\right)$ and lowest in the accession NRCRI (White) (0.02 $\left.\mathrm{t} \mathrm{ha}^{-1}\right)$ and (Table 7).

The fresh tuber yield of the non-grafts varied from $0.08 \mathrm{t} \mathrm{ha}^{-1}$ in the accession Bokkos 2 to $0.13 \mathrm{t} \mathrm{ha}^{-1}$ in the accession Langtang. The accessions did not differ significantly $(\mathrm{P}>0.05)$ in fresh tuber yield. Fresh tuber yields of the non-grafts were generally higher than the mean stock effects of the respective grafted accessions (Tables 7 and 8).

\section{Discussion}

The total dry matter accumulation increased with time in all the grafts, irrespective of the stage of growth. More dry matter was, however, accumulated in the leaves and the stems than in the tubers. At the later stages, dry matter distributed to the leaves decreased in favour of the stems and tubers. However, the percentage of dry matter distributed to the tubers was generally lower than the proportion distributed to the leaves and stems. This may explain why the fresh tuber yield in the Hausa potato is generally low. It has been suggested that the lack of balance between the source potential and sink capacity could affect the tuberous root yield (Namo, 2005). The rate of translocation of assimilates from the source to the sink is also believed to affect the tuberous root yield (Namo, 2005). Kooman and Rabbinge (1996) identified three phases of development in tuberous root crops: in the first phase, biomass is distributed preferentially to the leaves and stems; in the second phase, the biomass flow toward new and existing leaves is reduced because of the initiation and bulking of tubers; in the third phase, the tubers are the organs with the highest filling capacity and the only organs that continue to grow until harvest, 
while the aerial parts start to senesce. Unlike the other root and tuber crops, however, the period of production of new leaves (leaf area duration) in the Hausa potato is relatively longer, resulting in competition for assimilates between the photosynthetic leaves (source) and the tubers (sink). This competition appears to be in favour of the leaves, resulting in the generally low fresh tuber yield, as observed in this study.

The results of this study showed that harvest index increased with time up to 90 days after grafting in most of the grafts. Harvest index, or utilizable fraction, has been defined as the ratio of yield to the above-ground biomass (Forbes \& Watson, 1992). Harvest index is also defined as the ratio of the economic part (in this case tuber weight) to the total biomass (top weight plus tuber weight) (Donald, 1962; Harper \& Ogden, 1970). Harvest index is a tool used to estimate the yield potential of a crop. The harvest index observed in this study was generally low towards the end of the growing season, suggesting that most of the dry matter produced during the growing season was not translocated to the tubers but used by the newly formed leaves. On the other hand, Namo (2005) observed that harvest index in the reciprocal grafts of sweetpotato grown in the Jos-Plateau, Nigeria, increased with crop age and that the peak period varied with genotypes.

The rootstock-scion ratio varied from 0.16 in the self-graft of NRCRI (White) to 0.97 in the graft involving accessions NRCRI (White) as stock and Bokkos 2 as scion. The mean stock effect differed in the accessions; the mean scion effect was lowest in the accession NRCRI (White) and highest in the accession Manchok 2. These values were generally lower than those reported for sweetpotato grafts in the Jos-Plateau environment by Namo (2005).
The rootstock-scion, or simply root-top, ratio is related to the sink capacity of tuberous root crops. Namo (2005) demonstrated, through reciprocal grafting in the sweetpotato, that tuber yield is largely sink-determined. A variety with a large sink capacity has the potential to capture a higher proportion of assimilates produced during the growing season, which may lead to a high tuberous root yield (Mbaga, 2007). The generally low rootstock-scion ratio observed in this study may be attributable to the competition for assimilates between the newly produced leaves and the tubers. This may explain why fresh tuber yield in the Hausa potato is low when compared with the sweetpotato.

The fresh tuber yield was generally low in all the grafts, ranging from $0.03 \mathrm{tha}^{-1}$ to $0.09 \mathrm{t} \mathrm{ha}^{-1}$. The differences were, however, not significant. The mean stock effect on fresh tuber yield did not differ amongst the accessions. The mean scion effect was highest in the accession Bokkos 2 and lowest in the accession NRCRI (White). The fresh tuber yields of the non-grafts were generally higher than the mean stock effects of the respective grafted accessions. The generally low fresh tuber yield in the study confirms the findings by Namo and Opaleye (2018). The results of this study suggest that fresh tuber yield in the Hausa potato is not just a product of the dry matter production and distribution but, among other factors, the rate of translocation of same from the source to the sink.

\section{Conclusion}

The study has shown that total dry matter accumulated increased from 45 to 90 days after grafting in nearly all the grafts. The proportion of dry matter partitioned to the leaves decreased with time while that of stems 
and tubers increased up to 90 DAG. Generally, the percentage of dry matter distributed to the tubers was lower than that of the leaves and the stems. Harvest index increased with time in most of the grafts throughout the cropping season. The fresh tuber yields of the grafted accessions were generally lower than those of the non-grafts (control). The results suggest that apart from dry matter production and distribution, the size and activities of the source and sink could play a major role in the productivity of the Hausa potato.

\section{REFERENCES}

Alleman, J. (2002) Evaluation of Plectranthus esculentus N.E.Br. as a Potential Vegetable Crop. Ph.D Thesis, University of Pretoria, Pretoria, South Africa. p. 273.

Donald, C.M. (1962) In search of yield. Journal of Australian Institute of Agricultural Science 28, $171-178$.

Forbes, J.C. \& Watson, R.D. (1992) Plants in Agriculture. Cambridge University Press, Cambridge. 355p.

Harper, J.L. \& Ogden, J. (1970) The reproductive strategy of higher plants. 1. The concept of strategy with special reference to Senecio vulgaris L. Journal of Ecology 58, 681 - 698.

Kana, H. A., Aliyu, I. A. \& Chammang, H. B. (2012) Review on Neglected and Underutilized Root and Tuber Crops as Food Security in achieving the Millennium Development Goals in Nigeria. Journal of Agriculture and Veterinary Sciences 4, 27 - 33.

Kooman, P. L. \& Rabbinge, R. (1996) An Analysis of the Relation between Dry MatternAllocation to the Tuber and Earliness of Potato Crop. Annals of Botany 77, $235-242$.

Mbaga, Z. (2007) Quality and Yield Stability of Orange-Fleshed Sweet Potato (Ipomea batatas
L.) Varieties in different Agro-ecologies. M.Sc. Thesis. University of Zambia, Lusaka, Zambia.76p.

Namo, O. A. T. (2005) Screening for source-sink potentials in some sweet potato (Ipomoea batatas (L.) Lam.) Lines in Jos-Plateau, Nigeria. Published Ph.D. Thesis, University ofJos, Jos, Nigeria. Published by Lambert Academic Publishing, Omniscriptum $\mathrm{GmbH}$ Co.KG, Deutschland, Germany. 240p.

Namo, O. A. T. \& Opaleye, S. A. (2018) Assessment of Different Accessions of the Hausa Potato (Solenostemon rotundifolius (Poir)J.K. Morton) for Productivity in Jos-Plateau Environment. Journal of Agriculture and Ecology Research International 14 (3), 1 -9.

National Research Council (2006) Lost Crops of Africa: volume 11: vegetables. The National Academy Press, Washington, D.C., $268-285$.

Ñústez, C., Santos, M. \& Segura, M. (2009) Dry Matter Allocation and Partitioning of Four Potato Varieties (Solanum tuberosum L.) in Zipaquira, Cundinamarca (Colombia). Revista Facultad Nacional de Agronomia Medellin 62, $4823-4834$.

Oliveira, J.S., Brown, H.E., Gash, A. \& Moot, D.J. (2016) An Explanation of Yield Differences in Three Potato Cultivars. Agronomy Journal 108 (4), $1434-1446$.

Oteng-Yeboah, A. A. \& Bennett-Lartey, S. O. (2008) Ghana Country Report on the State ofPlant Genetic Resources for Food and Agriculture. In: Second report on the state of world's Plant Genetic Resources for Food and Agriculture Organization, 1 - 33.

PROTA (Plant Resource of Tropical Africa) (2013) Solenostemon rotundifolius Poir(Synonyms: Germania rotundifolius Poir, Plectranthus rotundifolius Sims) database. PROTA.org/ db/w-wpd/exec/db. Retrieved November 27. 
Schoeninger, M. J., Bunn, H. T., Murray, S.S. \& Marlett, J.A. (2000) Composition of Tubers used by Hadza Foragers of Tanzania. Journal of Food Composition and Analysis 13, 1 12.

Tekalign, T. \& Hammes, P.S. (2005a) Growth and Productivity of Potato as Influenced by Cultivar and Reproductive Growth I. Stomatal Conductance, Rate of Transpiration, Net Photosynthesis and Dry Matter Production and Allocation. Scientia Horticulturae 105, 13 27.
Tekalign, T. \& Hammes, P.S. (2005b) Growth and Productivity of Potato as influenced by Cultivar and Reproductive Growth II. Growth Analysis, Tuber Yield and Quality.Scientia Horticulturae 105, $29-44$.

Ukpabi, J. U., Oti, E. \& Ogbogu, N. (2011) Hausa Potato (Solenostemon rotundifolius) and Livingstone Potato (Plectranthus rotundifolius) Tubers in Nigeria. Journal of Stored Products and Postharvest Research 2 (6), $301-304$.

TABLE 1

List and sources of accessions used in the study

\begin{tabular}{lll}
\hline Accession No & Name & Source \\
\hline Accession 1 & NRCRI (White) & $\begin{array}{l}\text { National Root Crops Research } \\
\text { Institute (NRCRI), Kuru, Jos }\end{array}$ \\
Accession 2 & Bokkos 2 & Bokkos, Plateau State \\
Accession 3 & Manchok 2 & Manchok, Kaduna State \\
Accession 4 & Langtang & Langtang, Plateau State \\
\hline
\end{tabular}

TABLE 2

Physico-chemical properties of the top soil used for the experiment

\begin{tabular}{ll}
\hline Property & Value \\
\hline $\mathrm{P}^{\mathrm{H}}$ & 5.05 \\
Organic carbon $\left(\mathrm{g} \mathrm{kg}^{-1}\right)$ & 8.5 \\
Total Nitrogen $\left(\mathrm{g} \mathrm{kg}^{-1}\right)$ & 0.14 \\
Available phosphorus $\left(\mathrm{mg} \mathrm{kg}^{-1}\right)$ & 8.9 \\
Calcium & 4.12 \\
Magnesium & 1.02 \\
Potassium & 1.06 \\
Sodium & 3.4 \\
Cation exchange capacity (CEC) & 3.20 \\
\hline
\end{tabular}


TABLE 3

Dry matter accumulation (\%) in reciprocal grafts of four accessions of the Hausa Potato at different stages of growth in Jos

\begin{tabular}{|c|c|c|c|c|c|c|c|c|c|}
\hline \multirow{3}{*}{$\begin{array}{l}\text { Graft combination } \\
\text { Stock }\end{array}$} & \multirow[b]{3}{*}{ Scion } & \multicolumn{2}{|c|}{ Leaves } & \multicolumn{2}{|c|}{ Stem } & \multicolumn{2}{|l|}{ Tuber } & \multirow[t]{2}{*}{ Total } & \multirow[t]{2}{*}{$D M$} \\
\hline & & & & Days & After & Grafting & & & \\
\hline & & 45 & 90 & 45 & 90 & 45 & 90 & 45 & 90 \\
\hline Bokkos 2 & Bokkos 2 & 6.87 & 10.39 & 3.08 & 5.62 & 1.24 & 2.64 & 11.19 & 18.65 \\
\hline Bokkos 2 & NRCRI(White) & 5.30 & 13.03 & 2.92 & 12.28 & 2.75 & 6.23 & 10.97 & 31.54 \\
\hline Bokkos 2 & Langtang & 3.29 & 11.08 & 1.49 & 8.06 & 0.30 & 1.90 & 5.08 & 21.04 \\
\hline Bokkos 2 & Manchok 2 & 4.27 & 8.31 & 2.43 & 5.51 & 1.26 & 2.61 & 7.96 & 16.43 \\
\hline Langtang & Langtang & 0.82 & 1.63 & 0.34 & 1.00 & 0.09 & 0.56 & 1.25 & 3.19 \\
\hline Langtang & NRCRI(White) & 1.24 & 4.03 & 2.64 & 2.82 & 0.10 & 0.59 & 3.98 & 7.44 \\
\hline Langtang & Bokkos 2 & 2.12 & 12.60 & 0.56 & 7.70 & 0.16 & 1.71 & 2.84 & 22.01 \\
\hline Langtang & Manchok 2 & 3.17 & 0.81 & 1.76 & 0.28 & 1.20 & 0.59 & 1.25 & 3.19 \\
\hline Manchok 2 & Manchok 2 & 0.31 & 4.44 & 0.70 & 3.25 & 1.21 & 1.46 & 2.22 & 15.89 \\
\hline Manchok 2 & NRCRI(White) & 0.37 & 2.05 & 0.57 & 1.10 & 0.21 & 0.59 & 1.15 & 3.74 \\
\hline Manchok 2 & Bokkos 2 & 0.98 & 3.02 & 0.32 & 2.00 & 0.12 & 1.24 & 1.42 & 6.26 \\
\hline Manchok 2 & Langtang & 3.02 & 21.24 & 2.00 & 6.89 & 1.24 & 2.07 & 6.26 & 30.20 \\
\hline NRCRI(White) & NRCRI(White) & 5.00 & 3.75 & 2.42 & 3.94 & 1.29 & 0.76 & 8.71 & 8.20 \\
\hline NRCRI(White) & Bokkos 2 & 3.21 & 6.70 & 0.87 & 4.62 & 0.48 & 2.61 & 4.50 & 13.93 \\
\hline NRCRI(White) & Langtang & 0.48 & 2.04 & 0.68 & 1.19 & 0.21 & 0.99 & 1.37 & 4.22 \\
\hline NRCRI(White) & Manchok 2 & 0.50 & 9.02 & 1.48 & 7.67 & 0.43 & 1.16 & 2.41 & 17.85 \\
\hline SED & & 1.48 & & 0.86 & & 0.39 & & 2.49 & \\
\hline
\end{tabular}

SED-Standard error of difference

TABLE 4

Dry matter partitioning (\%) in different parts of reciprocal grafts of four accessions of the Hausa potato at different stages of growth in Jos

\begin{tabular}{|c|c|c|c|c|c|c|c|}
\hline \multicolumn{2}{|l|}{ Graft-combination } & \multicolumn{2}{|l|}{ Leaves } & \multirow{2}{*}{\multicolumn{2}{|c|}{$\begin{array}{l}\text { Stem } \\
\text { Grafting }\end{array}$}} & \multicolumn{2}{|l|}{ Tuber } \\
\hline & & & & & & & \\
\hline Stock & Scion & $\begin{array}{l}\text { Days } \\
45\end{array}$ & $\begin{array}{l}\text { After } \\
90\end{array}$ & 45 & 90 & 45 & 90 \\
\hline Bokkos 2 & Bokkos 2 & 65.31 & 55.71 & 27.52 & 30.13 & 7.17 & 14.16 \\
\hline Bokkos 2 & NRCRI(White) & 48.31 & 41.31 & 26.62 & 38.93 & 25.07 & 19.75 \\
\hline Bokkos 2 & Langtang & 64.76 & 52.66 & 29.33 & 38.31 & 5.91 & 9.03 \\
\hline Bokkos 2 & Manchok 2 & 53.64 & 50.78 & 30.53 & 33.54 & 15.83 & 15.89 \\
\hline Langtang & Langtang & 65.60 & 51.10 & 27.20 & 31.45 & 7.20 & 17.55 \\
\hline Langtang & NRCRI(White) & 31.16 & 54.17 & 66.33 & 37.90 & 2.51 & 7.93 \\
\hline Langtang & Bokkos 2 & 74.65 & 57.25 & 19.72 & 34.98 & 5.63 & 7.77 \\
\hline Langtang & Manchok 2 & 51.71 & 48.21 & 28.71 & 16.67 & 19.78 & 35.12 \\
\hline Manchok 2 & Manchok 2 & 13.96 & 27.94 & 31.53 & 20.45 & 54.75 & 9.19 \\
\hline Manchok 2 & NRCRI(White) & 32.17 & 54.81 & 49.57 & 29.41 & 18.26 & 15.76 \\
\hline Manchok 2 & Bokkos 2 & 69.01 & 48.24 & 22.54 & 31.95 & 8.45 & 19.81 \\
\hline Manchok 2 & Langtang & 48.24 & 70.33 & 31.95 & 22.82 & 19.81 & 6.85 \\
\hline NRCRI(White) & NRCRI(White) & 57.41 & 45.73 & 27.78 & 48.05 & 14.81 & 9.27 \\
\hline NRCRI(White) & Bokkos 2 & 72.15 & 48.10 & 19.08 & 33.17 & 10.53 & 18.74 \\
\hline NRCRI(White) & Langtang & 35.04 & 48.34 & 49.63 & 28.20 & 15.33 & 23.46 \\
\hline NRCRI(White) & Manchok 2 & 20.75 & 50.53 & 61.41 & 42.97 & 17.84 & 6.50 \\
\hline SED & & 1.48 & & 0.86 & & 0.39 & \\
\hline
\end{tabular}

SED-Standard error of difference 
Dry matter accumulation, distribution and fresh tuber yield ...

TABLE 5

Harvest index of reciprocal grafts of four accessions of the Hausa potato at different stages of growth in Jos

\begin{tabular}{|c|c|c|c|c|}
\hline Graft-Combination & & Days & After & Grafting \\
\hline Stock & Scion & 45 & & 90 \\
\hline Bokkos 2 & Bokkos 2 & 0.11 & & 0.14 \\
\hline Bokkos 2 & NRCRI(White) & 0.24 & & 0.19 \\
\hline Bokkos 2 & Langtang & 0.06 & & 0.09 \\
\hline Bokkos 2 & Manchok 2 & 0.34 & & 0.04 \\
\hline Langtang & Langtang & 0.07 & & 0.06 \\
\hline Langtang & NRCRI(White) & 0.03 & & 0.08 \\
\hline Langtang & Bokkos 2 & 0.06 & & 0.07 \\
\hline Langtang & Manchok 2 & 0.20 & & 0.07 \\
\hline Manchok 2 & Manchok 2 & 0.02 & & 0.06 \\
\hline Manchok 2 & NRCRI(White) & 0.14 & & 0.21 \\
\hline Manchok 2 & Bokkos 2 & 0.20 & & 0.08 \\
\hline Manchok 2 & Langtang & 0.08 & & 0.12 \\
\hline NRCRI(White) & NRCRI(White) & 0.15 & & 0.09 \\
\hline NRCRI(White) & Bokkos 2 & 0.06 & & 0.19 \\
\hline NRCRI(White) & Langtang & 0.15 & & 0.23 \\
\hline NRCRI(White) & Manchok 2 & 0.01 & & 0.06 \\
\hline SED & & 0.03 & & \\
\hline
\end{tabular}

SED-Standard error of difference

TABLE 6

Rootstock-scion ratio of reciprocal grafts of four accessions of the Hausa potato grown in Jos

\begin{tabular}{llllll}
\hline Stock & SOKKOS 2 & LANGTANG & MANCHOK 2 & NRCRI (White) & $\begin{array}{c}\text { Mean stock } \\
\text { (sink) effect }\end{array}$ \\
BOKKOS 2 & $\underline{0.07}$ & 0.17 & 0.92 & 0.38 & 0.39 \\
LANGTANG & 0.79 & $\underline{0.24}$ & 0.40 & 0.11 & 0.39 \\
MANCHOK 2 & 0.66 & 0.66 & $\underline{0.47}$ & 0.09 & 0.47 \\
NRCRI (White) & 0.97 & 0.26 & 0.89 & $\underline{0.16}$ & 0.57 \\
SED & & & 0.16 & 0.19 & \\
Mean scion (source) effect & 0.62 & 0.33 & 0.67 & & \\
SED & & & 0.17 & & \\
\hline
\end{tabular}

Figures underlined are for self-grafts. 
TABLE 7

Fresh tuber yield ( $\left(\mathrm{ha}^{-1}\right)$ of reciprocal grafts of four accessions of the Hausa potato grown in Jos

\begin{tabular}{llllll}
\hline \multirow{2}{*}{ Stock } & \multicolumn{5}{c}{ Scion } \\
\cline { 2 - 6 } & BOKKOS 2 & LANGTANG & MANCHOK 2 & NRCRI (White) & $\begin{array}{c}\text { Mean stock } \\
\text { (sink) effect }\end{array}$ \\
\hline BOKKOS 2 & $\underline{0.06}$ & 0.02 & 0.08 & 0.01 & 0.04 \\
LANGTANG & 0.09 & $\underline{0.03}$ & 0.05 & 0.02 & 0.05 \\
MANCHOK 2 & 0.04 & 0.06 & $\underline{0.04}$ & 0.02 & 0.04 \\
NRCRI (White) & 0.07 & 0.03 & 0.07 & $\underline{0.03}$ & 0.05 \\
SED & & & 0.04 & 0.02 & \\
Mean scion (source) effect & 0.07 & 0.04 & 0.06 & \\
SED & & & 0.01 & \\
\hline
\end{tabular}

Figures underlined are for self-grafts.

TABLE 8

Fresh tuber yield (tha ${ }^{-1}$ ) of non-grafts of four accessions of the Hausa potato grown in Jos

\begin{tabular}{ll}
\hline Accession & Total tuber yield $\left(t \mathrm{ha}^{-1}\right)$ \\
\hline BOKKOS 2 & 0.08 \\
LANGTANG & 0.13 \\
MANCHOK 2 & 0.12 \\
NRCRI White & 0.09 \\
LSD $_{0.05}$ & 0.11 \\
\hline
\end{tabular}

